\title{
The Impact of COVID-19 on Financial Statements Results and Disclosure: First Insights from Italian Listed Companies
}

\author{
Veronica Tibiletti $^{1{ }^{1 *}}$, Pier Luigi Marchini ${ }^{1}$, Valter Gamba ${ }^{2}$, Dina Lucia Todaro ${ }^{1}$ \\ ${ }^{1}$ Department of Economics and Management, University of Parma, Parma, Italy \\ ${ }^{2}$ Department of Management, University of Turin, Turin, Italy
}

Received October 7, 2020; Revised December 16, 2020; Accepted January 20, 2021

\section{Cite This Paper in the following Citation Styles}

(a): [1] Veronica Tibiletti, Pier Luigi Marchini, Valter Gamba, Dina Lucia Todaro , "The Impact of COVID-19 on Financial Statements Results and Disclosure: First Insights from Italian Listed Companies," Universal Journal of Accounting and Finance, Vol. 9, No. 1, pp. 54 - 64, 2021. DOI: 10.13189/ujaf.2021.090106.

(b): Veronica Tibiletti, Pier Luigi Marchini, Valter Gamba, Dina Lucia Todaro (2021). The Impact of COVID-19 on Financial Statements Results and Disclosure: First Insights from Italian Listed Companies. Universal Journal of Accounting and Finance, 9(1), 54 - 64. DOI: 10.13189/ujaf.2021.090106.

Copyright $C 2021$ by authors, all rights reserved. Authors agree that this article remains permanently open access under the terms of the Creative Commons Attribution License 4.0 International License

\begin{abstract}
In March 2020, given the extended and dangerous nature of the Covid-19 virus, the Italian government issued measures geared towards containing the effect of the pandemic, thereby identifying the national territory as a protected area and limiting the movement of people. This had great repercussions on the productive activities of businesses, which were forced to suspend production. Strong uncertainties, tied both to the time frame, as well as to the impact of Covid-19 on micro and macroeconomic levels, have made it extremely difficult to forecast what future outcomes might be in the short term, that is to say, it is related to the year 2020, and, specifically, on assumptions regarding the future operations of companies. This manuscript proposes a study of financial reporting, as required by accounting standards, which listed companies must provide in regard to disclosure due to Covid-19 as well as in regard to being a going concern. After having examined the main measures adopted by the Italian government, and after having outlined the existing literature on the relevance of the accounting information, an investigation is undertaken to analyze if the companies demonstrated, or failed to demonstrate, consistency in the reporting on future performance, by means of a comparison of what was represented in the financial statements for the year ended on December, 31, 2019, and the results actually achieved as of June, 30, 2020. It will be shown that negative judgments frequently emerge relating to future
\end{abstract}

performance and that no critical issues attributable to going concern were found.

Keywords Financial Statement, Financial Disclosure, COVID-19, Future Performance, Value Relevance

\section{Introduction}

The preparation of the annual financial statements is subject to a series of accounting principles aimed at ensuring proper reporting to provide stakeholders with a clear representation of the companies' economic and financial situation. Given the unprecedented nature of the difficulty that the Italian economy is facing at this moment in time, this study aims to analyse the information provided in the financial statements and/or related documents, and, particularly, in the notes of comment of Italian listed companies on their assumptions related to going concern. This is a fundamental premise identified by the Legislator in order to guarantee the true and fair representation of the business of the company consistently with the provisions of the IAS/IFRS accounting standards, and, more specifically, with the IAS 1 principle about the Presentation of the Financial Statement. The latter establishes that, during the 
preparation of the financial statements, the company's management must carry out a prospective assessment of the company's ability to continue to constitute a well-functioning economic entity meant to produce income for a foreseeable future period, relating to a period of at least twelve months from the reporting date ${ }^{1}$. As is well known, if directors believe that, although the use of the assumption of going concern is appropriate, there are uncertainties of a magnitude to raise significant doubts about the ability of the company to continue its activities, these must be clearly stated, in compliance with the provisions of accounting standard IAS 1 , paragraph 23 , in the notes of comment to the financial statement ${ }^{2}$. If significant uncertainties are identified regarding this capacity, information relating to the risk factors, the assumptions made, and the uncertainties identified, as well as the future business plans to deal with such risks and uncertainties, must be clearly provided in the notes of comment. The reasons that qualify the uncertainties as significant and the repercussions they may have on going concern must also be explained ${ }^{3}$. In the current economic context, the Covid-2019 pandemic has brought with it enormous uncertainty and has appreciably reduced the performance of most companies, such that the preparers of the financial statements, as well as the users, have placed (or should have placed) great attention on the issue of evaluating the premise of going concern. In fact, in cases of an inadequate assessment of going concern, a critical aspect might be that incorrect estimates have been made about company performance. The difficult economy and market conditions produced by the Covid-19 pandemic have also induced some Italian Regulators (Bank of Italy, CONSOB, and ISVAP) to issue a document on the disclosure to be provided in financial statements, in which specific reference is made to going concern ${ }^{4}$. At the national regulatory level (article 2423-bis paragraph 1 no. 1 of the Italian Civil Code and OIC 295), the need to verify going concern in the long term (usually 12 months) was considered essential in order to make an optimal choice with regards to the valuation criteria to be applied in the presentation of the financial statements ${ }^{6}$.

With regards to the aforementioned issues, it should be noted that, according to Italian national accounting

1 Ias 1, paragraph 23.

2 As regards the bank, financial, and insurance balance sheets, the references to the notes in the financial statements must be understood as the "the explanatory notes".

3 Ias 1 , paragraphs 23 and 24

4 Bank of Italy / Consob / Isvap document no. 2 of February 6, 2009, p. 5 Information to be provided in financial reports on going concern, financial risks, checks for devaluation of assets and uncertainties in the use of estimates.

5 OIC is the national accounting standard setter in Italy, like IASB for Europe.

6 Marcello R., "la continuità aziendale nella crisi di impresa", Fondazione Nazionale di ricerca dei commercialisti, 2015. standards, there may be events subsequent to the closing date of the financial statements that can invalidate the assumption of going concern, deriving from a worsening of the total net income but also of the financial performance of the company after the end of the financial year - factors necessary for assessing whether it is still appropriate to apply the assumption of going concern ${ }^{7}$. Taking into account the enormous difficulties in expressing an opinion in the current climate of uncertainty, and with the purpose of neutralizing the effects of the current economic crisis, the Italian Legislature has provided, with the introduction of the L.D. 23/2020, a framework of reference concerning the valuation of items with consideration for continuity for financial statements that had been finalized prior to February, 23, 2020 and not yet approved. In fact, it was established ${ }^{8}$ to revise the financial statements in progress in which forecasts had changed, or not, as a result of the pandemic in the last annual financial statements finalized prior to February, 23, 2020. The objective of the Italian Legislator was to satisfy the need to preserve the economic activity of the companies by keeping it protected from the effects of Covid-19, or by neutralizing the negative effects of the events that have emerged by being a going concern. For the financial statements drafted or in progress as of December, 31, 2020, anchorage to the continuity existing before the pandemic remains a possible option, one left to the discretion of the Board of Directors ${ }^{9}$. Despite Italian law, it is clear that the reporting burden on the preparers of financial statements is particularly relevant. This is especially the case given that the document must contain the necessary information regarding going concern assessed on "historical values" (as a reference). These could well be in contrast with negative operating trends, in terms of economic performance, which can be extracted from the data that might already have been obtained at the approval date of the financial statements and that were derived from the past achievements of management.

Therefore, with reference to the current situation of the industries most affected by the spread of Covid-19, there is an obligation to indicate in the notes of comment any uncertainties that may give rise to significant doubts on the adequacy of the assumption of going concern in drafting the financial statements. Moreover, the most relevant key element concerns the verification of the information regarding the existence of such circumstances and the appraisal by the Board of directors, which can only be accomplished by reading the notes of comments inside the financial statement.

\footnotetext{
7 Organismo Italiano di Contabilità, OIC n. 29.

8 Article 7, paragraph 1, D.L. 23/2020.

9 Abriani N., Cavalluzzo N., "Continuità aziendale valutata alla data del 31 dicembre 2019" Quotidiani del Sole 24 Ore.
} 


\section{Theoretical Background}

The financial statement is the principal tool for representing corporate information to stakeholders. The increasingly global nature of business and the role that financial information plays in international markets have increased the demand for the uniform regulation of financial reporting. With this goal in mind, the International Accounting Standards Board (IASB), in collaboration with leading accounting standards setters from various Countries, has accelerated efforts to produce a set of globally accepted international accounting standards $[19,34]$. The guideline regarding the disclosure to be produced in the financial statements is also identified in the IAS/IFRS international accounting standards ${ }^{10}$. As we know, it is through the financial statements that the companies provides information such as offering explanations about their performance, the criteria adopted, or about the company's future outlook, which is illustrative of the fact that the stakeholders are interested in the correlation between what the company will face in the future in comparison to what it has faced in the past.

Adequate financial reporting is understood as a way to implement a transparent process within companies in order to ensure that shareholders and stakeholders. In general, it can access information fairly and simultaneously $[32,22,23]$. Information transparency is understood to mean how organizations that participate in securities markets are obliged to provide adequate, truthful, and timely information regarding their operations or their target market $[29,25]$. The primary reason for the importance of transparency, as well as for any additional qualitative characteristics of financial information, is to provide information about business activities to investors, lenders and other existing and potential creditors, so as to give them a clear vision of how to allocate resources in the capital market $[8,30]$. The transparency, reliability, relevance and quality of financial information are of primary importance for capital market actors as they help investors make optimal decisions [14]. As is well known, stakeholders assess the risk of a company's insolvency by referring to financial information, and, therefore, having high quality information at their disposal is valuable for them because it reduces risk $[15,28]$.

Some Authors [24] have shown how a high level of disclosure of information in financial reporting can significantly increase corporate liquidity thanks to input from external stakeholders. According to other Authors [20], the quality of accounting information can mitigate

10 IAS 24, paragraph 1, specifies that when the company has a history of profitability and easy access to financial resources, the conclusion that the going concern assumption is appropriate can be reached without detailed analysis. the negative effects of information asymmetry and reduce the costs of adverse selection, which, in turn, allow companies to reduce their level of cash. Some studies that refer to financial statement information are limited to research contexts and aim to measure the quality and usefulness of the financial statements in order to verify the "relevance" that the same information can assume within the capital market $[2,17,18]$.

In respect to the concept of relevance of financial statement information, this represents a general principle of accounting and the preparation of financial statements, which is governed by art. 2423 of the Italian Civil Code was described in operational terms (preparation of economic and financial information) by IAS 1, OIC 11 and by the IASB Framework. It has been and is widely studied in the literature through the methodology defined as "value relevance". The latter one represents one of the areas of accounting research that began in the late 1960s $[4,7]$. Within this research area, many scholars have analyzed the relevance of financial information, focusing on different accounting standards $[3,9,10]$ or on the specific accounting values [1,7]. If financial information is to be useful, it must be relevant and faithfully represent what it purports to represent. The usefulness of financial information is enhanced if it is comparable, verifiable, timely and understandable". Basic qualitative characteristics of financial statements are relevance and faithful presentation. "Relevant financial information is capable of making a difference in the decisions made by users. Information may be capable of making a difference in a decision even if some users choose not to take advantage of it or are already aware of it from other sources" 11 . This area of study is mainly based on financial information contained in a research context that aims to measure the quality and usefulness of the financial statements, as well as the related economic and financial information. In other words, research on value relevance is based on the importance of financial information and the role that such information can have in the capital market. Capital market research on accounting has seen an explosive growth in the number of studies examining the relevance of financial statements and correlated information $[2,17,19]$.

The objective of the report is to provide necessary and useful information for potential venture capitalists rather than for lenders or other stakeholders. In order to better describe the subject, it may be useful to look at the "conceptual framework", that is the conceptual schemes that, by means of theoretical principles, enable the drafting of a company's financial statements. The Conceptual Framework laid out by the IASB highlights the existing relationship between the qualitative

11 Conceptual Framework, 2010. 
characteristics and the principle of usefulness of the financial statement information, distinguishing the fundamental qualities (its relevance and its connection with materiality and faithful representation) from other qualities to improve them. Information is defined as "material" when its omission or incorrect representation influences the decisions of stakeholders - decisions made on the basis of financial statement information.

The qualification of materiality must be considered along with other positive qualities, such as comparability, verifiability, timeliness and comprehensibility, in that they are additional tools to ensure the efficacy of the financial statements for stakeholders ${ }^{12}$. As defined by the International Accounting Standards Board (IASB), financial information is relevant when it contains specific qualitative characteristics capable of making a difference in the decisions made by stakeholders. Financial information can make a difference in decisions if it assumes a predictive value, if used to predict future results and control value, and if it allows for comparison with previous assessments (IASB, 2014).

Some Authors $[9,11,13,21]$ state that higher quality in accounting information translates into lower earnings, further arguing that research on value relevance is not only important to investors but also provides useful accounting information for standard setters and other users.

As we know, the recipients of financial information are not the only subjects who put liquidity into the company (otherwise known as capital providers ${ }^{13}$ ) but, more broadly, they encompass all the stakeholders, who must be enabled to appreciate the solvency and the liquidity of the company from a forward-looking perspective ${ }^{14}$. Relevant information comprises what readers need to evaluate a company's value and make decisions [31].

However, when examining the relevance of accounting information, it could be argued that this is not a unique term of measurement because different stakeholder groups may have different opinions regarding the relevance of the value of the information for assessment purposes [26,33].

Some Authors [6] have maintained that the investors' need for information does not have to be novel to be relevant but can be considered relevant when summarizing accounting information drawn from other sources. In other words, considering how many factors

12 IASB, The conceptual framework for Financial Reporting, Chapter 1, QC10.

13 Capital providers should be understood as the "existing and potential investors, lenders and other creditors", considered preferential recipients of economic and financial information, as outlined by the Conceptual Framework for Financial Reporting issued by the IASB

14 Regarding the recipients of economic and financial information, see INCOLLINGO, Information, p. 325 and ss. The Author also emphasizes that the richness of the information content of the financial statements for its multiple recipients is demonstrated by the fact that this type of document lends itself to various reworkings that lead to further and different ways of representing the results. could affect the opinion of stakeholders and, at the same time, prevent financial statements from fully covering the needs of investors ${ }^{15}$, there would be a risk of an influence on the quality of financial information $[11,12]$; this is related to the fact that financial statements are not the only font of information which leads investors to seek relevant information from other sources [31]. The statement of information is considered relevant when its omission or incorrect indication could reactively influence the decisions taken by users on the basis of the company financial statements (Art. 2 Direttiva 2013/34/ue).

The disclosure required by IAS 1 is intended to help users of the financial statements, since again, in terms of gathering information, it could help stakeholders understand the assessments made by directors on the future and on other fundamental causes of uncertainty in estimates. The disclosure (i.e., the nature of the assumptions or other causes of uncertainty, the sensitivity of the financial statement values to the methods, all the fundamental assumptions and estimates adopted, and the explanation of any changes made compared to the previous year, etc.) may vary depending on the nature of the assumptions themselves and on other circumstances. In this light, and in consideration of the current financial and economic crisis, it seems appropriate that the directors pay the utmost attention when providing adequate and exhaustive information regarding the reasons underlying the decisions taken and the assessments.

To make the information more relevant, it is possible to insert in the notes to the financial statements a series of informational elements directly and indirectly linked to the consequences of the health emergency, in order to highlight the resulting effects, subdividing them into the different functional areas: operating activities, investment activities, financing activities and restructuring and/or business model change activities.

\section{Sample and Research Methodology}

\subsection{Sample}

"To be useful, financial information must not only represent relevant phenomena, but it must also faithfully represent the phenomena that it purports to represent"16. Exactly for this reason, the intent of this study was to analyse the faithful representation of financial statement information in order to verify whether what is provided in the descriptive documents coincides with the results of the

15 Financial Accounting Standards Board (FASB). (1978), "Statement of Financial Accounting Concepts No. 1, Objectives of Financial Reporting by Business Enterprises" available at: http://www.fasb.org (accessed 11 August 2015)

16 Conceptual Framework, 2010. 
analyzed period. In other words, we investigated the content and relevance of firms' narrative disclosure about the effects of the Covid-19 crisis in annual statutory financial statements for listed Italians firms. We analysed communication regarding changes in financial reports, even when the changes relate to accounting rather than economic events. We made use of a specific capital market and financial reporting event, namely the crisis resulting from Covid 19, to examine the interaction between the disclosure provided and actual results. Starting with the full population of Italian listed firms at the end of the year 2020 (282 companies), we randomly selected 152 of them, excluding financial firms because of the uniqueness of their accounts and financial disclosure.

\subsection{Research Methodology}

For these 152 firms, we hand-collected information from the end of the year, 31.12.2019 financial statements, and from the 0.06.2020 and 30.06.2019 interim financial statements. The interim financial statements referring to 30.06.2019 were necessary in order to be able to clearly and reliably compare the financial statements with the interim financial statements as at 30.06.2020.

The aim of using different periods is to capture the effects of Covid-19 on the financial disclosure and on the going concern of the companies.

The purpose of this study is to analyse how the main listed companies in Italy have addressed the issue of impacts and going concern in the context of the economic crisis caused by the Covid-19 health emergency.

From a methodological point of view, due to the limited period taken into consideration for the study of financial information in a period of economic crisis, we have used a manual content analysis. Content analysis is one of the most used methods in accounting reporting research [27]. There are numerous alternative possibilities for applying this method (Unerman, 2000), and in this document, an analysis of the manual content was performed in order to examine the information contained within the accounting reports. One of the most recurrent features of content analysis is its consideration as a research technique for analyzing communications, describing their content, and making deductions regarding their effects [16]. The accounting information analysed for the research was collected using a two-step process. In the first step, we collected data manually from the AIDA Database. An empirical sample of 152 listed Italian companies was taken into consideration. The annual financial statements of each company as of December, 31, 2019 were extracted and analysed through a manual content analysis of the information that each company reported in the notes of comment and in the management report. As a technique for gathering data, content analysis involves sorting qualitative and quantitative information into pre-defined categories to derive patterns in the presentation and reporting of information [5].

The interim financial statements drawn up in 2020 and 2019 were extracted for the same companies, and, through a manual analysis, we were able to compare the data for the interim period 2019 with the interim financial statements for 2020 (interim financial statements drawn up on June, 30, 2020), in order to assess the impacts that the epidemic and the period of suspension of activities have had on the economic and financial performance of the company on 2019 , as well as the coherence of the information provided by the company with respect to the up-to-date performance ${ }^{17}$, regarding the information itself as compared with the final results in 2020 .

The interval of time analysed is, therefore, considered to be between 30.06.2019 and 30.06.2020, within which these consequent assumptions have been put in place:

- examination of the financial statements as of 31.12.2019 with particular emphasis on information on the effects of COVID-19 and on going concern;

- critical analysis of company performance as of 30.06 .2020 compared to the same period of the previous year in order to identify a correlation between the forecasts on management trends and the short-term data, in the form of a comparison between information contained in the financial statements as of 31.12.2019 and performance based on final data as of 30.06 .2020 .

\section{Results}

\subsection{Financial Statement Disclosure}

In light of this, from these financial statements drawn up at 31.12.2019, the descriptive financial statements document in which the companies disclosed information regarding the effects of the pandemic was analysed. We have thus extracted the explanatory notes and the management report, extracting the paragraphs in which such information is reported. It became clear that more references were made to the effects of the pandemic in the management report than in the notes of comment. The latter, in fact, is a tool containing information of a quantitative and qualitative nature on the data reported in the financial statements, which show the drafting and classification criteria used and the main risks to which it is exposed.

The information relating to going concern, on the other hand, must be reported in the notes of comment only when the Board of Directors deems there are relevant and significant doubts on going concern; otherwise, any risks have to be reported in the management report. In fact, for

17 The comparison of quantitative data required the identification of "comparable" periods, namely 30.06.2019 and 30.06.2020 
each macro-sector of the activities analysed, the information is mainly provided in the disclosures of the management report "Foreseeable evolution by management" and "Events after balance sheet date".

In addition, industries that have suffered the largest impact of the pandemic provide more information, also considering as disclosure the paragraph dedicated to the analysis of risks, such as liquidity and credit risk, and other specific paragraphs such as the "Letter to Shareholders".

The following table (Table 1) shows in which paragraphs the above information was provided, highlighting how the companies, in addition to highlighting the events that occurred after the end of the financial year, have provided transparency of information on specific items of balance.

Table 1. Types of disclosure in the financial statements as of 31.12.2019

\begin{tabular}{|c|c|c|c|c|}
\hline . & \multicolumn{2}{|c|}{ Explanatory Notes } & \multicolumn{2}{|c|}{$\begin{array}{c}\text { Management } \\
\text { Report }\end{array}$} \\
\hline $\begin{array}{l}\text { Disclosure } \\
\text { Paragraph }\end{array}$ & $\begin{array}{c}\text { Disclosure } \\
\text { present }\end{array}$ & $\%$ & $\begin{array}{c}\text { Disclosure } \\
\text { present }\end{array}$ & $\%$ \\
\hline Introductory Section & 8 & $5 \%$ & 40 & $26 \%$ \\
\hline $\begin{array}{l}\text { Regarding specific } \\
\text { balance sheet items }\end{array}$ & 57 & $38 \%$ & $\mathrm{n} / \mathrm{a}$ & $\mathrm{n} / \mathrm{a}$ \\
\hline $\begin{array}{l}\text { Foreseeable } \\
\text { evolution of } \\
\text { management }\end{array}$ & $\mathrm{n} / \mathrm{a}$ & $\mathrm{n} / \mathrm{a}$ & 118 & $78 \%$ \\
\hline $\begin{array}{c}\text { Post balance sheet } \\
\text { events }\end{array}$ & 78 & $51 \%$ & 92 & $61 \%$ \\
\hline Risk analyses & $\mathrm{n} / \mathrm{a}$ & $\mathrm{n} / \mathrm{a}$ & 74 & $49 \%$ \\
\hline Specific paragraph & $\mathrm{n} / \mathrm{a}$ & $\mathrm{n} / \mathrm{a}$ & 43 & $28 \%$ \\
\hline Other & 44 & $29 \%$ & 76 & $50 \%$ \\
\hline
\end{tabular}

It was also deemed appropriate to analyse the attention paid to the matter by the supervisory bodies, such as the Italian board of statutory auditors and auditing firms; the same bodies, in fact, should check the adherence of the actions taken by the companies regarding anti-Covid 19 legislation issued by the government.

It emerged, as shown in the following table (Table 2), that for $59 \%$ of the companies analysed, the board of statutory auditors described the health emergency in its report, monitoring how much was implemented by the Board of Directors.

With regard to the audit firms, only for $11 \%$ of the companies do the auditors express their opinion about that subject, given that their function is to weigh in on the truthfulness and correctness of the financial statements and on the compliance with its principles of preparation, which includes going concern.
Table 2. Report of Supervisory Boards

\begin{tabular}{|c|c|c|}
\hline Report of supervisory boards & Disclosure & $\%$ \\
\hline Board of statutory auditors & 89 & $59 \%$ \\
\hline Audit firms & 17 & $11 \%$ \\
\hline
\end{tabular}

When the latter is compromised, the auditor has the duty to make it explicit. In $11 \%$ of the cases examined, the current health emergency could influence, according to the auditor, the going concern. Below is a list of the concrete reasons, among those examined, that prompted the auditors to express their opinion:

- Covid-19 has generated greater uncertainty regarding the fair value measurements of the real estate portfolio;

- the health emergency adds further uncertainty about the achievement of the auditing objectives, both economic and financial, defined in the budget and business plan. Failure to achieve these results in the 2020 financial year could cause the failure of one or more financial parameters (covenants) of the existing loan agreements, with the forfeiture of the benefit and the consequent lack of liquidity necessary for the companies to meet contractual commitments;

- necessary changes to the business plan to adapt them to the impacts of Covid-19 and the negative results of the first months of 2020;

- verification of sensitivity analyses of the assumptions adopted in the preparation of the impairment tests, carried out with consideration for the probable effects of the pandemic.

\subsection{Information Coherence}

To understand how much the pandemic has effected listed companies, it was deemed useful to carry out an analysis by sector, that is to divide the sample into macro categories and analyze how each of them had suffered (or benefitted from) the effects of Covid-19. To affirm whether a company has suffered negative effects from Covid-19, it was necessary to establish a criterion so as to examine how this evolved in the first months of 2020.

To do this, we first proceeded to download and analyze the financial statements from 31.12.2019, which as we know are drawn up within 120 days, or 180 days in certain circumstances ${ }^{18}$, from the end of the administrative period.

More specifically, as shown in the following Table 3, in the sample examined from 31.12.2019, it was discovered

18Art. 106 of the D.L. of 17 March 2020,n. 18 established the possibility of calling the assembly to approve the budget within 180 days of the end of the financial year regardless of the statutory and statutory provisions. It is considered sufficient to mention the decision in the management report or, in case of exemption, in the explanatory note. 
(thanks to the information provided) that $40 \%$ of the companies were affected in the first three months of 2020 by the effects of the pandemic, which manifested for most of them in a drop in revenue.

The other $60 \%$ of the sample, on the other hand, declared, in the notes of comment or in the management report, how Covid-19 had not affected (or will not affect) the company's revenue nor going concern, thus not carrying any risk in a broad sense. Therefore, the same data from the sample were extrapolated, using the financial statements as of 30.06 .2020 as the reference period, so as to examine their consistency in terms of financial reporting, comparing them with the data relating to 2019 .

In this light, with reference to the financial data reported on a half-yearly basis for two administrative periods, that is the data from 30.06.2020 compared with the data from 30.06 .2019 , it was discovered that $70 \%$ of the companies had suffered significant effects on their financial position due to an average drop in revenue of $21 \%$.

In essence, among the companies in the sample analysed, $50 \%$ showed a lack of information consistency.

In fact, when drawing up the financial statements from 31.12 .2019 , about $60 \%$ of the sample, most of them belonging to the industrial and energy sector, declared that they had not suffered negative effects on going concern deriving from Covid-19, stipulating that, to the contrary, they experienced an increase in sales.

Table 3. Covid-19 effects on companies defined on the basis of its impact on revenues, comparing 30.06.2020 with 30.06.2019

\begin{tabular}{|c|c|c|c|c|c|c|}
\hline Covid-19 effect & \multicolumn{2}{|c|}{ 31.12.2019 } & \multicolumn{3}{|c|}{30.06 .2020} & 30.06 .2020 \\
\hline Business sector & NO & YES & $\mathrm{NO}$ & YES & TOT. & $\begin{array}{c}\text { Average Reduction in } \\
\text { Revenue }\end{array}$ \\
\hline Clothing and fashion & 7 & 4 & 0 & 11 & 11 & $-25 \%$ \\
\hline Food & 5 & 6 & 6 & 5 & 11 & $+13 \%$ \\
\hline Other & 4 & 2 & 4 & 2 & 6 & $-15 \%$ \\
\hline Automotive & 6 & 0 & 0 & 6 & 6 & $-29 \%$ \\
\hline Business Consulting & 10 & 4 & 10 & 4 & 14 & $-15 \%$ \\
\hline Consumer products & 5 & 8 & 3 & 10 & 13 & $-22 \%$ \\
\hline Culture & 3 & 3 & 1 & 5 & 6 & $-35 \%$ \\
\hline Publishing & 6 & 3 & 0 & 9 & 9 & $-5 \%$ \\
\hline Energy & 10 & 9 & 7 & 12 & 19 & $-18 \%$ \\
\hline Raw materials & 1 & 3 & 0 & 4 & 4 & $-14 \%$ \\
\hline Pharmaceutical & 4 & 0 & 3 & 1 & 4 & $+26 \%$ \\
\hline Pipelines & 2 & 3 & 1 & 4 & 5 & $-19 \%$ \\
\hline Personal services & 1 & 1 & 1 & 1 & 2 & $-19 \%$ \\
\hline Waste disposal & 1 & 1 & 1 & 1 & 2 & $-8 \%$ \\
\hline Sport & 2 & 0 & 0 & 2 & 2 & $-26 \%$ \\
\hline Industrial & 19 & 9 & 8 & 20 & 28 & $-18 \%$ \\
\hline Telecommunication & 4 & 0 & 2 & 2 & 4 & $-9 \%$ \\
\hline Transportation & 1 & 5 & 0 & 6 & 6 & $-35 \%$ \\
\hline Grand Total & 91 & 61 & 45 & 107 & 152 & \\
\hline
\end{tabular}


After an analysis of the revenue from 30.06.2020, compared with the corresponding interim period, only $20 \%$ of them showed a real increase, with the others having an average decrease in revenue of $19 \%$. Furthermore, in terms of the operating results of these companies, there was a significant negative impact of $42 \%$, on average.

To better understand, in detail, how listed companies dealt with such an unpredictable and uncertain event, it was necessary to analyse one of the most immediate indicators for assessing the solvency along with the level of overall debt given by the "Net financial position" indicator (hereinafter NFP), widely used in financial statement analysis, which is aimed at assessing the sustainability of financial debt ${ }^{19}$.

This indicator, calculated through obtaining the difference between the sum of liquidity and financial receivables and the amount of financial liabilities, makes it possible to assess not only the overall level of debt of the company but the company's ability to repay the debt when compared to revenue or the solidity of the equity structure as compared to the shareholders' equity.

The company's ability to repay its debts may also depend on its ability to generate sufficient positive cash flows to pay its lenders. These positive flows derive from sales or from ordinary operations. In this sense, we can obtain two indicators that relate the net financial position to revenues; a lower ratio of this indicator indicates a faster financial recovery which would also emerge in the case below. Instead, to analyze the state of dependence deriving from third parties, it is possible to use the NFP in relation to the net assets (NA). As the indicator grows, business solidity worsens, but in the case of the sample analyzed, continuous business solidity is shown.

As can be seen from Table 4, and, even more markedly, in Figure 1, analysing the data that emerged from 30.06.2020, it is clear that, despite a decline in revenue, the companies do not present major problems in covering liabilities with the liquidity deriving from sales. Figure 1 also shows an information consistency of the companies that declared that they do not have covid related effects.

Therefore, to carefully analyse the absorption rate of the net financial exposure, the sales return index and the net debt index were calculated. The first allows us to enter into the merits of the company's ability to ensure coverage of financial needs through sales. Only a decrease in this indicator shows the ability to absorb debt through the production of cash flow.

Figure 2 shows, just the information of the companies that have declared that they do not have an effect deriving from Covid-19 and how, in terms of corporate solidity, the

19 "La posizione finanziaria netta quale indicatore alternativo di performance" Fondazione Nazionale dei Commercialisti, 2015. debt indicator had decreased on average for the entire sample under analysis, thus presenting a solidified equity component.

In fact, with the D.L. n. 76, published on July 16, 2020, the Italian government adopted new provisions, mainly applicable to listed Italian companies, aimed at simplifying and accelerating the procedure for approving and executing capital increases.

It is certainly true that these indicators must be related to actual business performance, but the salient information lies in the dynamics of the indicators themselves, identifying, for example, the reason for which the company has generated or absorbed cash in a given period, in as much as the dynamics of the indicators are more important than the indicator itself. Two of the few sectors that have benefited from the pandemic are the pharmaceutical and agri-food sectors. Food and beverages, in fact, are practically the only products to have marked positive changes: large-scale distribution recorded a growth of $13 \%$, mainly relating to "Made in Italy" products $^{20}$.

All companies in the sector have continued their operations at full speed while in compliance with the safety regulations issued by the government through the creation of specific Internal Control Committees.

Although the significant increase in revenues is due to the momentary increase in sales due to the lockdown, the companies have tried to leverage the increase in profit margins of the products sold. Furthermore, the unprecedented growth of e-commerce should not be underestimated: online sales, which companies have strengthened (or introduced), increased by $85 \%$ compared to 2019 with a value of 854 million euros ${ }^{21}$.

The pharmaceutical sector, on the other hand, which has around 20,000 active companies and generates 90 billion euros in revenue, has proved immune to the virus in terms of maintaining profit margins and their propensity to invest, thanks to the solidity of the companies and the financial flexibility that has allowed an extraordinary reflex speed to the crisis.

After this analysis of Covid-19 impacts on listed companies in different industries, there is no doubt that the listed companies have been affected in different ways and to different extents. Apart from the food and pharmaceutical industries, there was a significant reduction in revenue in the first half of 2020 compared to 2019. Not only that, other consequences are attributable to the increase in financial stress and economic uncertainty which is reflected in the volatility of capital, commodities, and the foreign exchange market ${ }^{22}$.

20 La spesa online in Italia, Il Sole24 ore, 2020.

21 La spesa online in Italia, Il Sole24 ore, 2020.

22 What impacts might COVID-19 have on our evaluation of management's going concern assessment?, KPMG, 2020 
Table 4. The net financial position December, 31, 2019 vs June, 30, 2020

\begin{tabular}{|c|c|c|c|c|c|c|}
\hline $\begin{array}{c}\text { COVID } \\
\text { EFFECT }\end{array}$ & NEP/REVENUE 2019 & NEP/REVENUE 2020 & $\begin{array}{c}\text { VAR. } \\
\text { NEP/REVENUE }\end{array}$ & $\begin{array}{c}\text { NFP/NA } \\
2019\end{array}$ & $\begin{array}{c}\text { NFP/NA } \\
2020\end{array}$ & $\begin{array}{c}\text { VAR. } \\
\text { NFP/NA }\end{array}$ \\
\hline YES & -8.38 & $-13,31$ & $-4,93$ & $-19,46$ & $-23,08$ & $-3,62$ \\
\hline NO & -.71 & $-1,61$ & $-0,90$ & 0.70 & $-0,71$ & -1.40 \\
\hline
\end{tabular}

\section{Index of Sales Returns}

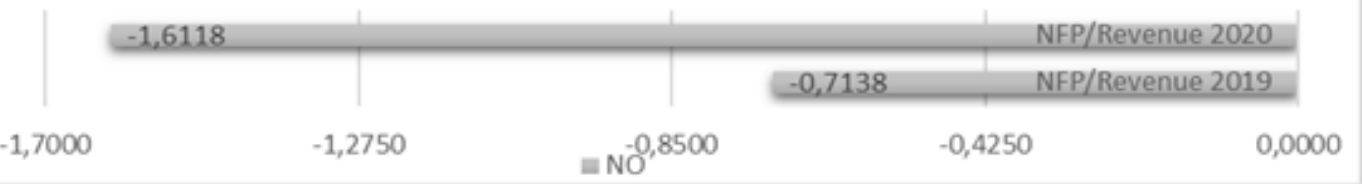

Figure 1. Comparative Index of Sales Returns 30 June, 2020 vs 30 June, 2019

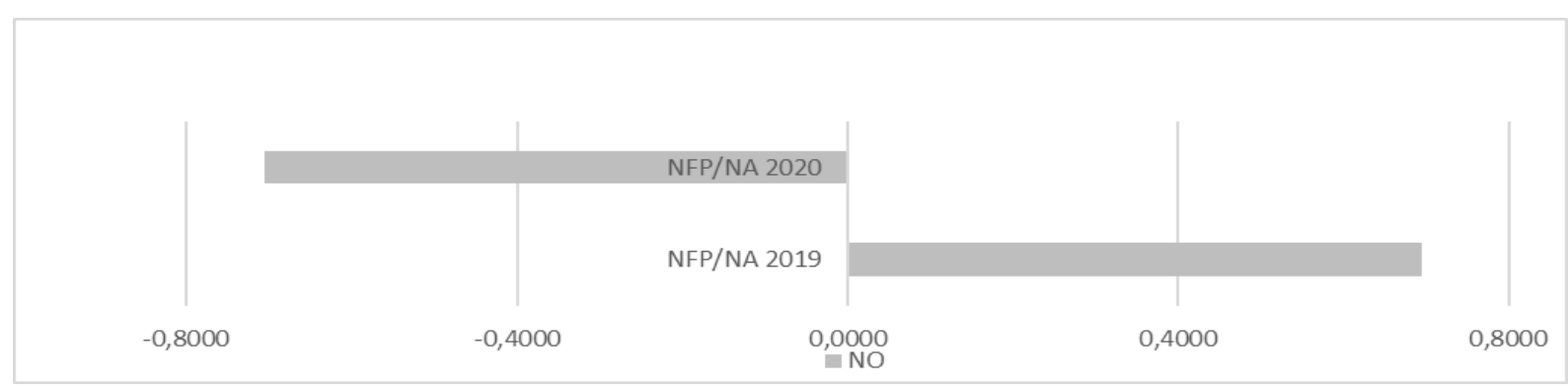

Figure 2. Comparative index of net debt June, 30, 2020 vs June, 30, 2019

As a response to these circumstances, many countries, including Italy, have issued decrees to support the affected companies, mainly aimed at lowering business costs, such as personnel costs through the request for unemployment benefits, and providing cash by favoring the access to $100 \%$ guaranteed loans subject to compliance with certain conditions (such as prohibition of dismissals and transfers of activities abroad).

The following graph (Figure 3) shows, for each sector analysed here, the reduction in the average revenues of listed companies whose revenue was negatively impacted by Covid19:

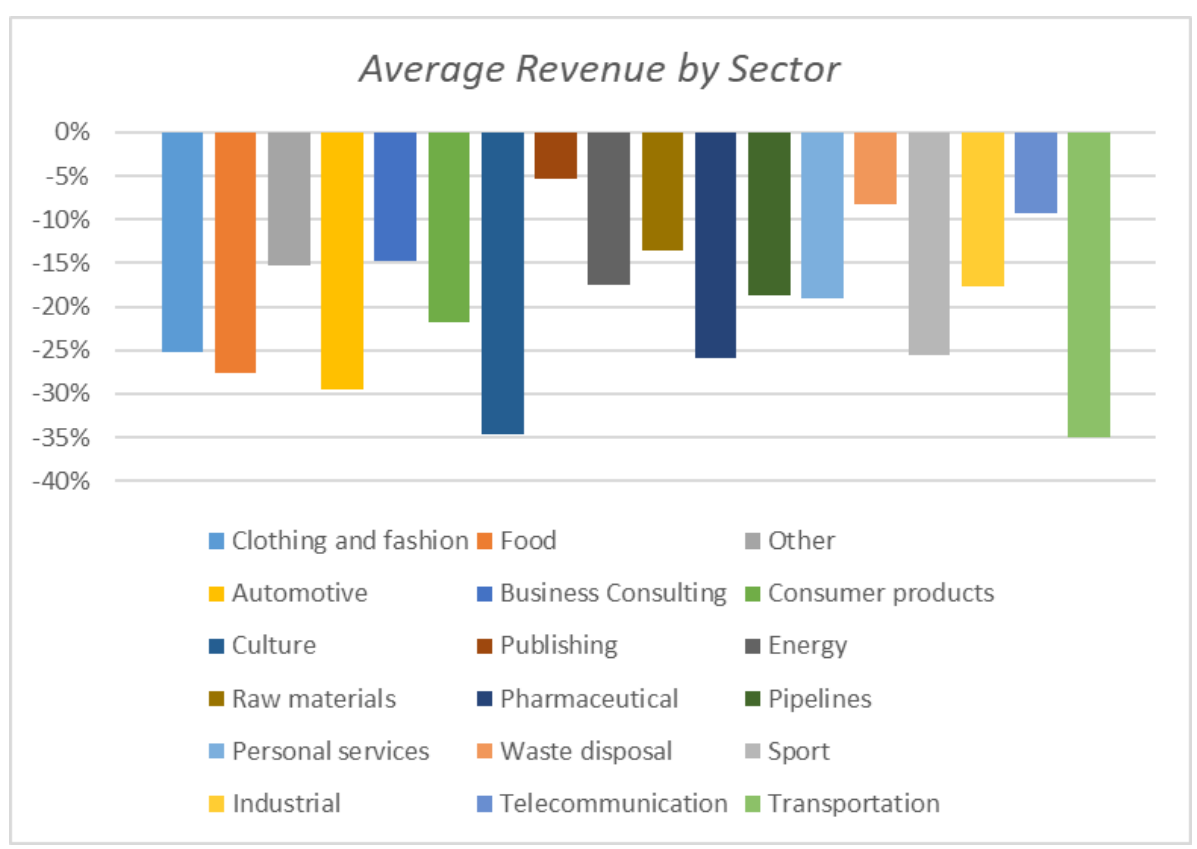

Figure 3. Reduction in average revenue by sector of listed companies whose revenue was negatively impacted by Covid-19. 


\section{Conclusions}

This study illustrates the first effects of the COVID-19 pandemic on corporate performance measured on the data existing on 30.06 .2020 of a sample of Italian listed companies.

Although it is necessary to distinguish the companies according to the sector to which they belong, if we want to draw some initial conclusions, it is possible to state excluding the food, pharmaceutical and healthcare sectors - that, among the companies belonging to the analyzed sample, there is a lack of information consistency in 50\% of cases.

Specifically, having identified the reference sample among the companies listed on the stock exchange, broken down by sector, critical issues were found by comparing what was declared in the financial statements as of December, 31, 2019 with the actual income performance that can be deduced from the final data as of June, 30, 2020.

Having acknowledged this inconsistency - shown, above all, by the contraction in revenues compared to what was declared, which suggests that the companies have underestimated the effects of COVID-19 on management performance - we wanted to investigate the assumptions of company going concern by re-presenting the aforementioned comparison, but with the use of other salient reference indicators: the NFP in relation to revenues or to shareholders' equity.

In regard to these factors, it was concluded, in terms of going concern, that the companies did not show particular problems or weaknesses and that they were consistent with what was reported in their financial statements.

Therefore, considering the exceptional nature of the event and the impossibility of putting in place reliable forecasts - being in the presence of an exogenous variable - it would certainly have been appropriate to give greater emphasis to the qualitative characteristics of the accounting information, and, above all, to prudence.

Our expectation is that our research activity will, therefore, be continued once the final data as of 31 December, 2020 are available and that the following activities will be undertaken:

- re-execute the assessments carried out, extrapolating and processing the data on company performance relating to the period from January, 1st to December, 31, 2020;

- acquire the information/statements on the prospective management performance (2021) and ongoing concern;

- verify the presence of any "justifications" in the event that there are still informational inconsistencies between what was declared in the financial statements as of December, 31, 2019 and the related company performance at the end of the 2020 financial year;
- $\quad$ analyze the relevance of balance sheet information on the capital market in the pre-Covid and post-Covid period using a statistical model.

\section{REFERENCES}

[1] Aboody, D. \& Lev, B., "The value relevance of intangibles: the case of software capitalization", Journal of Accounting research, vol. 36, pp. 161-191, 1998. https://doi.org/10.230 $7 / 2491312$.

[2] Alfraih, M. M., "The role of audit quality in firm valuation Evidence from an emerging capital market with a joint audit requirement", International Journal of Law and Management, vol. 58, no. 5, pp. 575-598, 2015. https://doi.org/10.1108/IJ LMA-09-2015-0049.

[3] Almujamed, H. I. \& Mishari, M. A., "Corporate governance and value relevance of accounting information: Evidence from Kuwait", International Journal of Ethics and System, vol. 36, no. 2, pp. 249-262, 2020. https://doi.org/10.1108/IJ OES-08-2019-0140.

[4] Ball, R. \& Brown, P., "An empirical evaluation of accounting income numbers", Journal of Accounting Research, vol. 6, no. 2, pp. 159-178, 1968 https://doi.org/10.2307/2490232.

[5] Baldini, M. A. \& Liberatore, G., "Corporate Governance and Intellectual Capital Disclosure. An empirical analysis of the Italian listed companies, Corporate Owership \& Control, vol. 13, no. 2, pp.186-308, 2016. https://doi.org/10.22495/coc.

[6] Bao, Y., "The value relevance of accounting information: evidence of asian stock market", Kent State University, Department of Mathematical Sciences, 2004.

[7] Bart, M. E., Beaver, W. H. \& Landsman, W. R., "Value-Relevance of Banks' Fair Value Disclosures under SFAS", The accounting review, vol. 71, no. 4, pp. 513-537, 1996. https://www.jstor.org/stable/248569.

[8] Barth, J.R., Caprio, G. \& Levine, R., "Bank regulation and supervision in 180 countries from 1999 to 2011 ", Journal of Financial Economic Policy, vol. 5, no. 2, pp. 111-219, 2013. https://doi.org/10.1108/17576381311329661.

[9] Barth, M. E., Landsman, W. R., \& Lang, M. H., "International accounting standards and accounting quality", Journal of Accounting Research, vol. 46, no. 3, pp. 467-498, 2008. https://doi.org/10.1111/j.1475-679X.2008.00287.x.

[10] Bartov, E., Goldberg, S. R., \& Kim, M., "Comparative value relevance among German, U.S., and international accounting standards: A German stock market perspective", Journal of Accounting, Auditing \& Finance, vol. 20, no. 2, pp. 95-119, 2005. https://doi.org/10.1177/0148558X050200 0201 .

[11] Beattie, V., McInnes, B. \& Fearnley, S., "Through the Eyes of Management: Narrative Reporting Across Three Sectors: Final Report", Centre for Business Performance: London, UK, 2004. ISBN: 9781841522364.

[12] Beattie, V., McInnes, B., \& Fearnley, S., "A methodology for analyzing and evaluating narratives in annual reports: A 
comprehensive descriptive profile and metrics for disclosure quality attributes", Accounting Forum, vol. 28, no. 3, pp. 205-236, 2004. https://doi.org/10.1016/j.accfor.2 004.07.001.

[13] Bukh, P. N., Nielsen, C., Gormsen, P. \& Mouritsen, J., "Disclosure of information on intellectual capital in Danish IPO prospectuses", Accounting, Autiding \& Accountability Journal, vol. 18, no. 6, pp. 713-732, 2004. https://doi.org/ $10.1108 / 09513570510627685$

[14] Bushee, B. J. \& Noe, C. F., "Corporate Disclosure Practices, Institutional Investors, and Stock Return Volatility", Journal of Accounting Research, vol. 38, pp. 171-202, 2000. https://doi.org/10.2307/2672914.

[15] Carmo, M. B., Afondo, A. P., Ferreira, A., Clàudio, A. P. \& Silva, G., "PoI Awareness, Relevance and Aggregation for Augmented Reality", International Conference Information Visualisation, Lisbon, 2016, pp. 300-305.https://doi.org/10. 1109/IV.2016.47

[16] Castilla, P. F., \& Ruiz, R. C., "Content analysis within intangible assets disclosure: a structured literature review", Journal of Intercullectual Capital, vol. 18, no. 3, pp. 505-543, 2017. https://doi.org/ 10.1108/JIC-11-2016-0123

[17] Cho, C.H., \& Patten, D.M., "The role of environmental disclosures as tools of legitimacy: a research note", Accounting, Organizations and Society, vol. 32, no. 7, pp. 639-647, 2007. https://doi.org/10.1016/j.aos.2006.09.009.

[18] Clarkson, P. M., Fang, X. H., Li, Y. \& Richardson, G., "The relevance of environmental disclosures: are such disclosures incrementally informative?", Journal of Accounting and Public Policy, vol. 32, no. 5, pp. 410-431, 2013. https://doi.org/10.1016/j.jaccpubpol.2013.06.008.

[19] Gallery, G., Cooper, E. \& Sweeting, J., "Corporate Disclosure Quality: Lessons from Australian Companies on the Impact of Adopting International Financial Reporting Standards", Austrialian Accounting Review, vol. 18, no. 46, pp. 3-20, 2008. https://doi.org/10.1111/j.1835-2561.2008.0 030.x.

[20] Garcìa-Teruel, P. J., Martìnez-Salano, P. \& Sànchez-Ballesta, J. P., "Accruals quality and corporate cash holdings", Accounting and Finance, vol. 49, no. 1, pp. 95-115, 2009. https://doi.org/10.1111/j.1467-629X.2008.00 276.x.

[21] Graham, R., King, R. \& Bailes, J., "The value relevance of accounting information during a financial crisis: Thailand and the 1997 decline in the value of the Bath", Journal of International Financial Management and Accounting, vol. 11, no. 2, pp. 84-107, 2000.https://doi.org/10.1111/1467-6 46X.00057.

[22] Greiling, D. \& Spraul, K., "Accountability And The Challenges Of Information Disclosure", Public Administration Quarterly, vol. 34, no. 3, pp. 338-377, 2010. https://www.jstor.org/stable/41288352.

[23] Healy, P. M. \& Palepu, K. G., "Information asymmetry, corporate disclosure, and the capital markets: A review of the empirical disclosure literature", Journal of Accounting and Economics, vol. 31, pp. 405-440,
2001.https://doi.org/10.1016/S0165-4101(01)00018-0.

[24] Huang, R., Marquardt, C. A. \& Zhang, B., "Why do managers avoid EPS dilution? Evidence from debt-equity choice", Review of Accounting Studies, vol. 19, pp. 877912, 2014. https://doi.org/10.1007/s11142-013-9266-3.

[25] Ilserver, J. \& Leung, R., "Review of Evidence between Corporate Governance and Mandatory IFRS Adoption from the Perspective of Agency Theory and Information Asymmetry", Universal Journal of Accounting and Finance, vol. 1, no. 3, pp. 85-94, 2013. https://doi.org/10.13189/ujaf. 2013.010301 .

[26] Inchausti, B. G., "The influence of company characteristics and accounting regulation on information disclosed by Spanish firms", European Accounting Review, vol. 6, no. 1 , pp. 45-68, $1997 . \quad$ https://doi.org/ $10.1080 / 096381897336863$.

[27] Krippendorff, K, "Reliability in Content Analysis, Some Common Misconceptions and Reccomendatios", Human communication research, vol. 30, no. 3, pp. 411-433, 2004. https://doi.org/10.1111/j.1468-2958.2004.tb00738.x

[28] Leuz, C. \& Verrecchia, R. E., "The Economic Consequences of Increased Disclosure", Journal of Accounting Research, vol. 38, pp. 91-124, 2000. https://doi.org/10.2307/2672910.

[29] Nguyen, T. M. H., Nguyen, N. T., Nguyen, H. T., "Factors Affering Voluntary Information Disclosure on Annual Reports: Listed Companies in Ho Chi Minh City Stock Exchange", Journal of Asian Finance, Economics and Business, vol. 7, no. 3, pp. 43-62, 2020. https://doi.org/10.13106/jafeb.2020.vol7.no3.53.

[30] Shakesperare, C., "Reporting matters: the real effect of financial reporting on investing and financing decisions", Accounting and Business Research, vol. 50, no. 5, pp. 425-442, 2020. https://doi.org/10.1080/00014788.2020.177 0928 .

[31] Shamki, D. \& Alulis, I. K. (2016), “Company's Characteristics and Accounting Information Relevance", Universal Journal of Accounting and Finance, vol. 4, no. 3, pp. 107-116, 2016. https://doi.org/10.13189/ujaf.2016.0403 02 .

[32] Smith, M. \& Taffler R. J., "The chairman's statement: A content analysis of discretionary Theoretical Frameworks in Research: Meaning and Implications for Researchers", Journal of African Interdisciplinary Studies, vol. 4, no. 5, pp. 53-64, 1996.https://doi.org/10.46769/jais.0119721465 83600143.

[33] Thinggard, F. \& Damkier. J., "Has financial statement information become less relevant? Longitudinal evidence from Denmark", Scandinavian Journal of Management, vol. 24, no. 4, pp. 375-387, 2008. https://doi.org/10.1016/j.scam an.2008.06.001.

[34] Wee, M., Tarca, A. \& Chang, M., "Disclosure incentives, mandatory standards and firm communicationin the IFRS adoption setting", Austrialian Journal of Management, vol. 39, no. 2, pp. 265-291, 2014. https://doi.org/10.1177/03128 96213481366. 